\title{
Changing Leadership Style in the Vietnamese Commercial Banks Before and After Vietnam Joins the WTO
}

\author{
Do Minh Cuong ${ }^{1} \&$ Nguyen Hai Minh ${ }^{1}$ \\ University of Economics and Business, Vietnam National University, Hanoi, Vietnam \\ Correspondence: Nguyen Hai Minh, University of Economics and Business, Vietnam National University, Hanoi, \\ Vietnam. E-mail: nghaiminh82@gmail.com
}

Received: May 31, 2016

doi:10.5539/ass.v13n2p1
Accepted: June 8, $2016 \quad$ Online Published: January 19, 2017

URL: http://dx.doi.org/10.5539/ass.v13n2p1

\begin{abstract}
This study seeks to examine the changes in leadership style in four state-owned commercial banks in Vietnam of Vietcombank, Vietinbank, BIDV and Agribank before and after Vietnam joins the WTO, from 2007 to 2015. The study used OCAI culture diagnostic models to assess four different leadership styles using questionnaires and multivariate analysis techniques (paired $t$ test, $t$ test, ANOVA). The research result from 1056 employees in Vietnamese banks shows that there is a shift in the leadership style between two periods before and after Vietnam joins the WTO. The study also shows a significant difference in the change level of the leadership style between banks that have increased competitive and creative factors. This conversion trend is strongly increasing as Vietnam is about to participate in the TPP.
\end{abstract}

The study was funded by Vietnam National Foundation for Science and Technology Development (NAFOSTED) under grant number I3-2012.21.

Keywords: Leadership style, organizational culture, commercial bank, OCAI model, bank administration

\section{Introduction}

Leadership style is a characteristic aspect of organizational culture and plays an important role to the organization success. Leadership style affects organization's performance, reputation or image (Conger \& Kanungo, 1988; Deal \& Kennedy, 1982). It is also regarded as one of the most crucial factors creating the difference in image, supporting the achievement of corporate performance as well as the achievement of strategic objectives and maintaining the organization's advantages (Bass, 1985). In addition, leadership style reflects the perspectives and philosophies on organizational management in order to maximize the use of resources, achieve the the organization's goals, and maintain the organization's position and image (Avolio, 1999; Quinn, 1988; Yukl, 2010).

Points of views on leadership style vary. Leadership style does not represent talent, purpose, control art and impacts of leadership to others (Avolio, 1999). Leadership style is considered as a system of characterized indications of a leader defined by personality traits (Burns, 1978) or simply put as the interactive result between personal relationships and events (Tichy \& Devama, 1986). Leadership style is also seen as the combination of subjective psychological factors and environmental factors in the management system (Schein, 1985).

Many researchers worldwide argue that in the different business stages, the nature of business or organizational structure requires different leadership style to match with corporate cultures. The leadership styles have also changed under the pressure from business environment due to increasing volatility in the business environment. According Quin \& Camaroon (2011), there are four leadership styles based on the corporate culture types. They are (1) the style of guides, leaders, spiritual leaders belonging to the clan culture; (2) the style of the supervisors and managers belonging to hierarchy culture; (3) the style of directors and commanding generals pertaining to market culture and (4) the style of music conductors and expedition leaders pertaining to Adhocracy (Create) culture. It should be noted that four leadership styles co-exist and each might express more obviously into a dominant cultural style of a leader and a particular organization, depending on the business stages as well as the business sector characteristics.

Becoming a WTO member in 2007 is a major event marking Vietnam's integration with the world economy. Vietnam's joining the TPP marks the next milestone of intensive, extensive and higher-level integration. The 
integration process brings both advantages and challenges for all businesses, including the banking sector. The competitive pressures shall increase for the state commercial banks when the financial market is increasing; more foreign banks enter the market and the private commercial banks is more and more developing. These pressures require the state commercial banks (owned by the government from $51 \%$ to $100 \%$ of the shares) to change, especially changing the organizational culture structure (Nguyen \& Dao, 2015). Therefore, to survive and thrive, the state commercial banks and businesses are expected to adapt to the business environment. Changes in leadership style or typology of leadership have been well-researched in developed countries. In Vietnam, despite pressures for competitiveness and pressures for changes, these issues remain under-researched. For this reason, this study was designed to evaluate the changes of leadership style in the Vietnamese state commercial banks and the difference in the change level of the leadership styles between the banks and the business sector.

\section{Research Overview}

Leadership style is characteristics of the leadership in managing and operating the organizations. There are many different perspectives on leadership style in organizations. Leadership style is defined as a personal characteristic which differentiates between a leader with other people without leadership qualities (Stodgill, 1948); is characteristic of a leader guiding the organization and is a part of the organizational culture (Harris \& Ogbonna, 1999; Schein, 1985); it is the characteristic system governed by the leader's personalities (Burns, 1978); is result between the personal relationships and the organization's events (Tichy \& Devama, 1986) or control art, which affects others (Avolio, 1999). Hence, the concept of the leadership style carries certain different connotations to different researchers. In this study, we define the leadership styles based on Schein's concept (1985) and Quin \& Camaroon (2011). Accordingly, leadership style is characteristics of management or operating work of the leaders and it is also an attribute of the organizational culture.

Research of leadership style could be traced back to the 1950s with main theories as (1) identification theory (Argyris, 1955; Mahoney et al, 1960; Bowsers \& Seashore, 1966); (2) organization approach theory (Bowsers \& Seashore, 1966) and (3) organizational culture and leadership style theory (Schein, 1985; Ogbonna \& Harris, 2000; Quin \& Camaroon, 2011).

Identification theory postulates that personal characteristics formed leadership style and certain personal characteristics shaping successful leaders (Argyris, 1955; Mahoney et al., 1960). The in-born characteristics made the leaders different to people without leadership qualities (Stodgill, 1948). Although identification theory helps to explain the leaders' success based on their personal characteristics, it was criticized for not showing how to categorize the characteristic features of successful leadership style.

Organization approach theory argues that leadership style depends on the organization's characteristics. These researches having used organization approach conclude that organizations in which leaders use democratic management style shall easily achieve their strategic goals as well as greater corporate performance because this leadership style shall prove the strength of the cohesion between collective and individuals' creativeness (Bowsers \& Seashore, 1966).

Table 1. Summary characteristics of 4 major organizational culture types

\begin{tabular}{|c|c|c|c|c|}
\hline & Clan culture & Hierarchy culture & Market culture & $\begin{array}{c}\text { Adhocracy (Create) } \\
\text { culture }\end{array}$ \\
\hline $\begin{array}{c}\text { Dominant } \\
\text { Characteristics }\end{array}$ & $\begin{array}{c}\text { Friendly and sharing } \\
\text { environment, }\end{array}$ & Principal, hierarchy & $\begin{array}{l}\text { Focus on results, boost } \\
\text { competition }\end{array}$ & $\begin{array}{l}\text { Free and dynamic } \\
\text { environment }\end{array}$ \\
\hline $\begin{array}{l}\text { Organizational } \\
\text { Leadership }\end{array}$ & $\begin{array}{l}\text { Guides, group leaders, } \\
\text { spiritual leaders }\end{array}$ & Supervisors, managers & $\begin{array}{l}\text { Directors, commanding } \\
\text { generals }\end{array}$ & $\begin{array}{c}\text { Conductors, } \\
\text { expedition leaders }\end{array}$ \\
\hline $\begin{array}{l}\text { Management of } \\
\text { Employees }\end{array}$ & $\begin{array}{l}\text { Cooperative, } \\
\text { collaborative }\end{array}$ & Stable, compliant & Promotive, challenging & Free, creative \\
\hline Organization Glue & Loyalty, tradition & $\begin{array}{l}\text { Regulations, rules, } \\
\text { standards }\end{array}$ & Victory, achievements & $\begin{array}{l}\text { Innovation, } \\
\text { experience }\end{array}$ \\
\hline Strategic Emphases & $\begin{array}{l}\text { Strong team } \\
\text { development }\end{array}$ & $\begin{array}{l}\text { Stable and steady } \\
\text { system }\end{array}$ & Market leader & $\begin{array}{l}\text { Continuous } \\
\text { innovation }\end{array}$ \\
\hline Criteria of Success & $\begin{array}{l}\text { Loyal and supportive } \\
\text { staffs }\end{array}$ & $\begin{array}{l}\text { Lowest costs, highest } \\
\text { standards }\end{array}$ & $\begin{array}{l}\text { Number one in market } \\
\text { share }\end{array}$ & Pioneering products \\
\hline
\end{tabular}

Leadership style and organizational culture theory (Schein, 1985; Quin \& Camaroon, 2011). Organizational culture and leadership style are considered as the core and inseparable parts (Harris \& Ogbonna, 1999). According to Schein (1992), leadership style and organizational culture are two inseparable and 
intimately-related parts: leadership style is a direct result of the organizational culture, but the leadership style have back impact to the organizational culture. Quin and Camarón (2011) state that there are four different leadership styles corresponding with four organizational culture types: Family culture (Clan), Hierarchy culture (Hierarchy), Competitive culture (Market) and Creative culture (Adhocracy). In addition, based on six elements of organizational culture such as: (1) Dominant Characteristics, (2) Organizational Leadership, (3) Management of Employees, (4) Organization Glue, (5) Strategic Emphases and (6) Criteria of Success. In particular, in Clan culture, leaders with outstanding competencies are instructors, team and spiritual leaders; in Hierarchy culture, leaders with outstanding competencies are the supervisors, and managers; in Market culture, leaders with outstanding competencies are directors and commanding generals; and in Adhocracy culture, leaders with outstanding competencies are conductors and expedition leaders (see Table 1).

\section{Hypotheses:}

Joining the WTO is a significant integration event. Along with that, financial sector also welcomes many international banks to the Vietnamese market such as Citibank, HSBC, ANZ and so on. These newly-entered financial institutions along with non-public banks shall create an increasing level of competitiveness to state commercial banks. In this view, banks have to change, including changes in organizational culture and leadership style. Therefore, this study suggests:

H1: There is change in the leadership styles of the state commercial banks before and after Vietnam had joining the WTO. Leadership style here is understood as a component and characteristics of organizational culture, which is more influential and enduring than a specific business leader's behavior style.

Different banks have the different characteristics of administrative systems and different cultural forms. The competitive level of market may affect the change trends of leadership style, but there may be differences between the banks. Therefore, this study suggests:

H2: There are differences in the changing level in different leadership styles between banks. However, these differences are in the framework of the 4 basic organizational culture types according to OCAI model, which have not created a specific leadership style of Vietnam yet.

Vietnamese economic history has recognized the difference between the North and the South of Vietnam in receiving the idea of market economy. The market economy has entered the South of Vietnam earlier, since before 1975 (when Vietnam War ended), and only interrupted for a period of 10 years. Meanwhile, the North developed towards economic planning of Soviet model from 1954s. Therefore, organizational culture's dynamics, characteristics are also marked with differences between the South and the North. Southern region has always been considered to be more dynamic than the North. These reasons can make the change of the leadership styles vary between the South and the North. Therefore, this study suggests:

H3. There are differences of change level in the different leadership styles between the South and the North.

\section{Research Methodology}

\subsection{Research Design}

The study was conducted through interviews with employees working at four largest state commercial banks in Vietnam, namely Agribank, Vietcombank, BIDV and Vietinbank through a structured questionnaire. The questionnaire aims to assess four main leadership styles and was adapted from the scale of the leadership style in OCAI organizational culture diagnostic questionnaires of Quin \& Camaroon (2011). The questions are used for both periods before and after Vietnam joined the WTO. Total points for the four questions are identified as 10 points per a personal answer. The questions were tested through a discussion group with 10 organizational culture specialists and revised before the official survey. Four leadership style groups surveyed include:

(1) Style of guides, group leaders, and spiritual leaders (Clan culture) with following survey questions:

A. The leadership in the organization is generally considered to exemplify mentoring, facilitating, or nurturing.

(2) Style of conductors, and expedition leaders (Adhocracy Culture) with following survey questions:

B. The leadership in the organization is generally considered to exemplify entrepreneurship, innovation, or risk taking.

(3) Style of directors, and commanding generals (Market culture) with following survey questions:

C. The leadership in the organization is generally considered to exemplify a no-nonsense, aggressive, results-oriented focus. 
(4) Style of supervisors, managers (Hierarchy culture) with following survey questions:

D. The leadership in the organization is generally considered to exemplify coordinating, organizing, or smooth-running efficiency.

\subsection{Sample Sizes and Data Collection Methods}

To ensure the study's reliability, our expected sample size is identified as 1000 . To achieve this sample size we have delivered 1500 questionnaires. Investigation method is done by both (1) the direct survey and (2) surveys via the internet. Direct survey is done in the bank branches in Hanoi and other areas are surveyed via the internet through email lists of all employees who are randomly selected from the list of employees working at selected banks. To ensure code of research, the questionnaires designed did not request name of employees in the research. Our obtained results are 1056 valid questionnaires, including 318 questionnaires of employees working at both the period before and after Vietnam joined the WTO.

Table 2. Breakdown of sample results

\begin{tabular}{|c|c|c|}
\hline \multicolumn{2}{|c|}{ Classification criteria } & Number of Respondents (\%) \\
\hline \multirow{2}{*}{ Gender } & Man & $456(40.6 \%)$ \\
\hline & Woman & $668(59.4 \%)$ \\
\hline \multirow{4}{*}{ Age } & $<25$ & $80(7 \%)$ \\
\hline & $25-35$ & $992(86.7 \%)$ \\
\hline & $35-45$ & $63(5.5 \%)$ \\
\hline & $45-55$ & $9(0.8 \%)$ \\
\hline \multirow{4}{*}{ Educational background } & Intermediate / College & $19(1.7 \%)$ \\
\hline & University & $863(76.2 \%)$ \\
\hline & MA & $247(21.8 \%)$ \\
\hline & $\mathrm{PhD}$ & $3(0.3 \%)$ \\
\hline \multirow{5}{*}{ Seniority at the Unit (Bank) } & $<2$ years & $114(10 \%)$ \\
\hline & $2-5$ years & $320(28.1 \%)$ \\
\hline & $5-10$ years & $642(56.4 \%)$ \\
\hline & $10-15$ years & $47(4.1 \%)$ \\
\hline & $>15$ years & $16(1.4 \%)$ \\
\hline \multirow{5}{*}{ Seniority in the bank profession } & $<2$ years & $139(12.3 \%)$ \\
\hline & $2-5$ years & $321(28.4 \%)$ \\
\hline & $5-10$ years & $612(54.2 \%)$ \\
\hline & $10-15$ years & $41(3.6 \%)$ \\
\hline & $>15$ years & $16(1.4 \%)$ \\
\hline \multirow{2}{*}{ Region } & The North & 905(78.7\%) \\
\hline & The South & $245(21.3 \%)$ \\
\hline \multirow{4}{*}{ Banks } & Vietcombank & $455(39.5 \%)$ \\
\hline & Agribank & $153(13.3 \%)$ \\
\hline & BIDV & $439(38.1 \%)$ \\
\hline & VietinBank & $105(9.1 \%)$ \\
\hline
\end{tabular}

\subsection{Data Analysis Methods}

To assess the change in leadership style between the two periods before and after Vietnam joined the WTO; first of all, we use average assessment scoring and standard deviation of the respondents in the two periods. Next, to assess the differences happening between the two periods we use Paired t test for assessing the movement of experienced personnel groups in both periods (Hair et al., 2006; Janssens et al., 2008; Bryman \& Bell, 2015; Field, 2009). To evaluate the differences in the change level of leadership style aspects between banks, and between business sectors we use t-test verification (applying for two areas) and ANOVA (for comparing between banks). Variable to compare these differences is calculated from four measuring variables of the leadership styles according to the formula: GapK = K2 - K1. Where: GapK is the change of the leadership styles; K1 is the assessment point of leadership styles in the periods before joining the WTO; K2 is the assessment point of the leadership styles in the periods after joining the WTO. 


\section{Research Results}

\subsection{The Leadership Style Change between the Two Periods}

The analysis results from data of 1056 respondents (318 people working in both periods) showed a downward trend in style "guides, leaders, spiritual leaders" of the Clan culture with a GPA of later stage as 2.840 (SD = 1.075 ) and the GPA of the period before joining the WTO as 3.189 (SD = 1.366). Similarly, the GPA of style "conductors, expedition leaders" of Adhocracy (Create) culture also declined from $2.371(\mathrm{SD}=1.003)$ in the period before joining the WTO to $2.323(\mathrm{SD}=0908)$ in the period after joining the WTO. Two leadership styles of "supervisors, managers" and "directors, commanding generals" tend to increase. In which the style of "supervisor, managers" of Hierarchy culture increased from $2.217(\mathrm{SD}=0.655)$ in the period before joining the WTO to 2.488 WTO $(\mathrm{SD}=0874)$ in the period after joining the WTO; in the style of "directors, commanding generals" of Market culture increased from $2.152(\mathrm{SD}=0.692)$ in the period before joining the WTO to 2.338 $(\mathrm{SD}=0.903)$ (Table 3; Figure 1).

Table 3. Evaluation results of the leadership styles in Vietnamese commercial banks between the two periods

\begin{tabular}{|c|c|c|c|c|}
\hline \multirow{2}{*}{ Leadership style } & \multicolumn{2}{|c|}{ Before joining WTO } & \multicolumn{2}{|c|}{ After joining WTO } \\
\hline & Mean & SD & Mean & SD \\
\hline $\begin{array}{l}\text { A. The leadership in the organization is generally considered to } \\
\text { exemplify mentoring, facilitating, or nurturing }\end{array}$ & 3.189 & 1.366 & 2.840 & 1.075 \\
\hline $\begin{array}{l}\text { B. The leadership in the organization is generally considered to } \\
\text { exemplify entrepreneurship, innovation, or risk taking }\end{array}$ & 2.217 & 0.655 & 2.488 & 0.874 \\
\hline $\begin{array}{l}\text { C. The leadership in the organization is generally considered to } \\
\text { exemplify a no-nonsense, aggressive, results-oriented focus }\end{array}$ & 2.152 & 0.692 & 2.338 & 0.903 \\
\hline $\begin{array}{l}\text { D. The leadership in the organization is generally considered to } \\
\text { exemplify coordinating, organizing, or smooth-running efficiency }\end{array}$ & 2.371 & 1.003 & 2.323 & 0.908 \\
\hline
\end{tabular}

Flexibility and Discretion

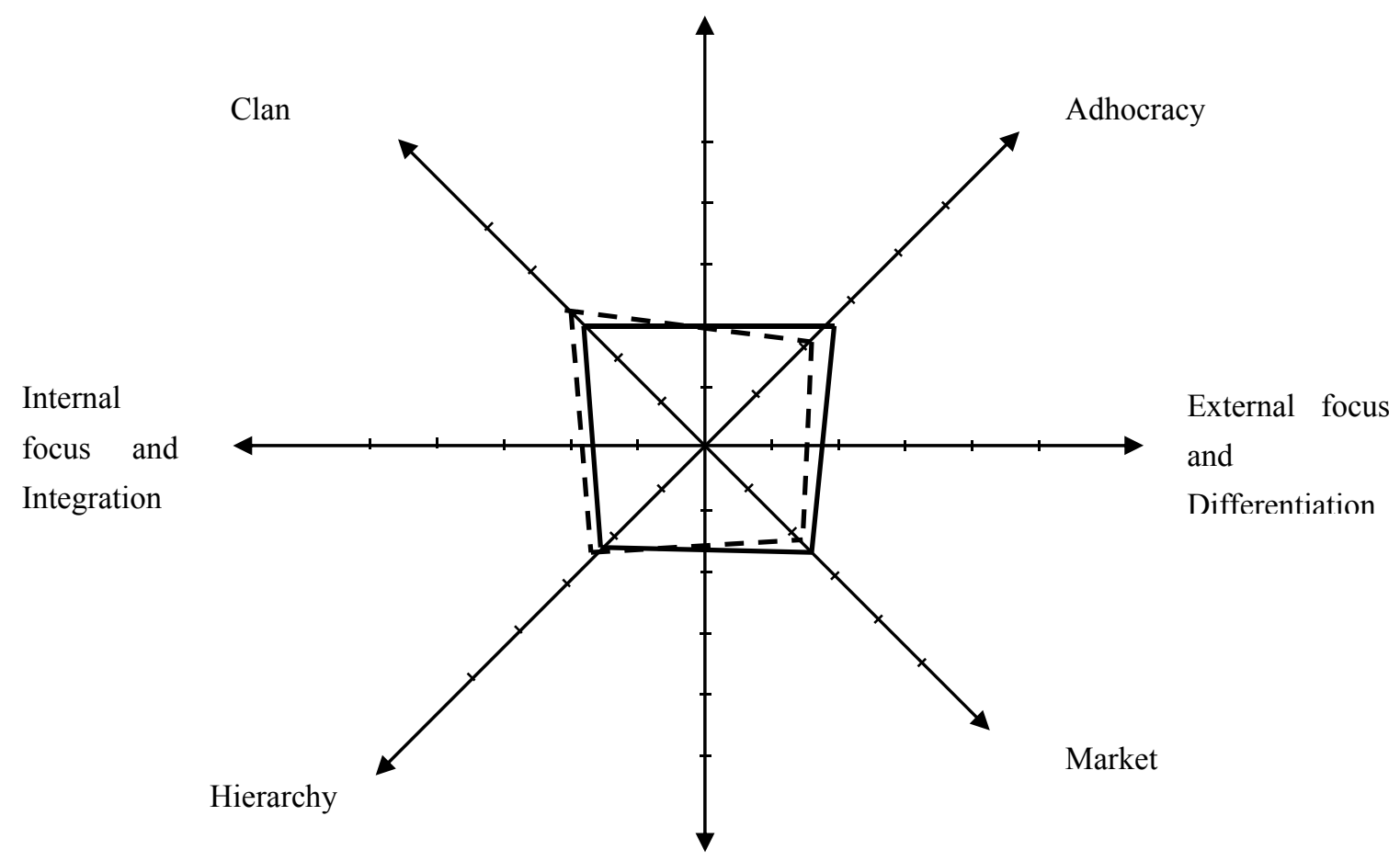

Stability and Control

$\longrightarrow$ Before joining WTO

After joining WTO

Figure 1. Changing leadership styles in the Vietnamese commercial banks before and after Vietnam joins the WTO 
To evaluate the real change in leadership styles in two stages before and after Vietnam joined the WTO; the authors used paired t test verification. Verification results also showed that there were differences in all four leadership styles of the four different organizational culture types between the two periods ( $p$-value $<0.05$ ) (Table 4). In other words, we accepted the research hypothesis H1. In particular, leaders tend reduced the style of "guides, leaders and spiritual leaders" of Clan culture and the style of "conductors, expedition leaders" of Adhocracy culture. Meanwhile, leadership style increased in the style of "supervisor, managers" of hierarchy culture and the style of "directors, commanding generals" of market culture (Table 4).

Table 4. Validation of results in changing leadership styles in the Vietnamese commercial banks before and after joining the WTO

\begin{tabular}{|c|c|c|c|c|c|}
\hline \multirow{3}{*}{ Leadership style } & \multicolumn{3}{|c|}{ Differences between two periods } & \multirow{3}{*}{$\mathrm{t}$} & \multirow{3}{*}{$\mathrm{p}$-value } \\
\hline & \multicolumn{3}{|c|}{$\operatorname{Mean}(\mathrm{SD})$} & & \\
\hline & $\begin{array}{l}\text { After joining } \\
\text { WTO }\end{array}$ & $\begin{array}{l}\text { Before joining } \\
\text { WTO }\end{array}$ & Differences & & \\
\hline $\begin{array}{c}A \text {. The leadership in the organization is generally } \\
\text { considered to exemplify mentoring, facilitating, or } \\
\text { nurturing }\end{array}$ & $2.671(1.037)$ & $3.164(1.360)$ & $-0.492(1.538)$ & -5.752 & $<0.001$ \\
\hline $\begin{array}{l}\text { B. The leadership in the organization is generally } \\
\text { considered to exemplify entrepreneurship, } \\
\text { innovation, or risk taking }\end{array}$ & $2.483(.785)$ & $2.216(.656)$ & $0.266(0.894)$ & 5.350 & $<0.001$ \\
\hline $\begin{array}{c}C . \text { The leadership in the organization is generally } \\
\text { considered to exemplify a no-nonsense, aggressive, } \\
\text { results-oriented focus }\end{array}$ & $2.660(.936)$ & 2.153(.697) & $0.508(1.161)$ & 7.862 & $<0.001$ \\
\hline $\begin{array}{l}\text { D. The leadership in the organization is generally } \\
\text { considered to exemplify coordinating, organizing, } \\
\text { or smooth-running efficiency }\end{array}$ & $2.182(.806)$ & 2.388(.998) & $-0.206(.990)$ & -3.738 & $<0.001$ \\
\hline
\end{tabular}

\subsection{The Difference of Change Level in the Leadership Styles between the Banks and the Business Sectors}

The analysis results showed that there were differences in change level of leadership style between different banks (p-value $<0.05$ ). In other words, we accepted the research hypothesis $\mathrm{H} 2$. With the style of guides, leaders and spiritual leader, points of Vietcombank and Vietinbank were downward trend, while points of Agribank and BIDV tended to increase (table). For style of supervisors and managers, three banks such as Vietcombank, Agribank and BIDV increased while Vietinbank tended to decline (table). For the style of directors and commanding generals, results of Vietcombank and Vietinbank increased, while results of Agribank and BIDV were downtrend (table). For the style of conductors and expedition leaders, the results showed that the two banks as Vietcombank and Vietinbank increased points, while the remaining two banks, Agribank and BIDV tended to decrease (Table 5).

Table 5. The validation of difference in change level in leadership styles between commercial banks

\begin{tabular}{|c|c|c|c|c|c|}
\hline Changing lea & p style & $\mathrm{N}$ & Mean & SD & p-value $(F)$ \\
\hline \multirow{4}{*}{ Clan culture } & Agribank & 45 & 0.189 & 1.125 & \multirow{4}{*}{$<0.001$} \\
\hline & Vietcombank & 158 & -1.316 & 1.578 & \\
\hline & BIDV & 101 & 0.455 & 0.900 & \\
\hline & Vietinbank & 19 & -0.289 & 0.887 & \\
\hline \multirow{4}{*}{ Hierarchy Culture } & Agribank & 45 & 0.267 & 0.720 & \multirow{4}{*}{0.011} \\
\hline & Vietcombank & 158 & 0.218 & 1.099 & \\
\hline & BIDV & 101 & 0.441 & 0.476 & \\
\hline & Vietinbank & 19 & -0.263 & 0.872 & \\
\hline \multirow{4}{*}{ Market culture } & Agribank & 45 & -0.100 & 0.857 & \multirow{4}{*}{$<0.001$} \\
\hline & Vietcombank & 158 & 1.127 & 1.214 & \\
\hline & BIDV & 101 & -0.158 & 0.578 & \\
\hline & Vietinbank & 19 & 0.342 & 0.883 & \\
\hline \multirow{4}{*}{ Adhocracy culture } & Agribank & 45 & -0.189 & 1.120 & \multirow{4}{*}{$<0.001$} \\
\hline & Vietcombank & 158 & 0.041 & 0.981 & \\
\hline & BIDV & 101 & -0.678 & 0.737 & \\
\hline & Vietinbank & 19 & 0.211 & 1.045 & \\
\hline
\end{tabular}


The change according to business sectors was also noted when analyzing the research results. Accordingly, there are differences in the change level of leadership styles between the North and the South ( $p$-value $<0.05$ ). In other words, we accepted the research hypothesis H3. In which, to the style of guides, leader and spiritual leaders tended to decrease more than the Southern groups. The style of supervisors and managers showed that the Southern groups declined while the North tended to increase. For the style of directors and commanding generals, the Southern groups tended to increase more than the Northern groups. For the style of conductors and expedition leaders, the Northern groups declined, whereas the Southern groups tended to increase (Table 6).

Table 6. Validation of difference in change level of leadership styles between the North and the South

\begin{tabular}{|c|c|c|c|c|c|}
\hline \multicolumn{2}{|c|}{ Leadership style/zones } & $\mathrm{N}$ & Mean & $\mathrm{t}$ & p-value \\
\hline \multirow{2}{*}{ Clan culture } & The North & 239 & -.111 & \multirow{2}{*}{8.266} & \multirow{2}{*}{$<0.001$} \\
\hline & The South & 84 & -1.577 & & \\
\hline \multirow{2}{*}{ Hierarchy Culture } & The North & 239 & .469 & \multirow{2}{*}{7.411} & \multirow{2}{*}{$<0.001$} \\
\hline & The South & 84 & -.310 & & \\
\hline \multirow{2}{*}{ Market culture } & The North & 239 & .140 & \multirow{2}{*}{-11.347} & \multirow{2}{*}{$<0.001$} \\
\hline & The South & 84 & 1.554 & & \\
\hline \multirow{2}{*}{ Adhocracy culture } & The North & 239 & -.446 & \multirow{2}{*}{-8.033} & \multirow{2}{*}{$<0.001$} \\
\hline & The South & 84 & .476 & & \\
\hline
\end{tabular}

\section{Discussion}

First, the major commercial banks' leadership style is an important component and dialectical relationship with the organizational culture system, which affects the banks' corporate performance more and longer than a particular leader's behavior style. In Vietnam, from the conventional leadership style as family based, hierarchical and bureaucratic leadership styles during the period of centralized planning management mechanism, the leadership style and organizational culture in state commercial banks have shifted toward more creative and competitive in the period of open-door and integration policy.

Research results acknowledge the characteristics of the Vietnamese state commercial banks' leadership style in both periods as introvert and flexible culture group, especially in the period before joining the WTO. Style assessment points of guides, leaders and spiritual leaders of the Clan culture and of supervisors, and managers were higher than the other styles. We also acknowledge the change in leadership style in all four styles. The general trend shows that the leadership style has shifted to extrovert organizational culture due to increasing points in market oriented culture of the style of directors and commanding generals, and increasing points in the style of supervisors and managers of hierarchy culture.

Despite the shift toward extrovert style, banks' predominant leadership style remains more introvert rather than extrovert. The state commercial banks' introvert and flexible style might be affected by specific cultural environment of Vietnam. Vietnam is a country influenced by Confucian and patriarchal character is a unique culture and affects the bank leadership's styles. The shift toward extrovert style showed the competitive pressure in the current banking sector that requires the banks to change. Especially, when Vietnam joined the WTO, the more participation of international banks and the expansion of private banks have impulsed the change in the state commercial banks. The trend of choosing market culture with the style of leadership's directors and commanding generals is dignified more and more. The leaders tend to find the ways to accommodate the market, seek stability and enhance control in the management and operating organization process.

Second, the change extent and speed of leadership styles model differ between state commercial banks, which depends on the business type (state-owned dominant shares or entire capital charter/ ownership) and the leadership capacity of its most senior management divisions.

Our research results also show the differences in the change level of the leadership styles between specific banks. While the state commercial banks such as Vietcombank and BIDV tend to strongly decline family properties in management, Agribank does not show any significant changes. This can be resulted from historic characteristics and the change of ownership types, administration models of the current state commercial banks. Vietcombank was, in the past established for the foreign trade purpose, in which they have contacted with foreign partners earlier and had more extrovert traditions than others. This bank is the first state-owned bank equitizing, changing from administration model into a modern, international standard and accepting the contribution shares of state private investors, including foreign investors. Cooperation and competition with foreign partners is an 
opportunity and challenge for VCB to improve competitiveness, innovation and creativeness in their leadership and its corporate administration. Meanwhile, Agribank was founded for the agricultural activities; because of the larger network, more complicated management system and worse leadership competencies change ability is slower. Currently, Agribank has planned to equitize, so openness and transparency in organization administration are bad. The recent business reports also showed that the corporate performance of Vietcombank, Agribank and BIDV is much better. It is also an evidence of innovation, adaptation of changing leadership style towards openness, flexibility, market-oriented and this may be a reason to create Vietcombank and BIDV's better corporate performance than Agribank's. This is also the objective reason and trend required the Vietnamese state commercial banks to equitize to change into more effective leadership model and modern management under international standards.

Thirdly, the change extent and speed of leadership style models also differed between geographical areas and Southern and Northern cultural areas. The study also showed differences in the change level of different leadership style aspects between the two Northern and Southern business areas. While the Southern region's leadership style changed faster and more extroverted, the Northern region's changed more slowly and tended to be more conservative. This may be resulted from differences in cultural characteristics between the South and the North. The South is considered the region approaching the market economy earlier, whose residents also are more open, liberal, receptive to new things, and more dynamic organizational culture than the North. This may explain the reason why the head offices, branches and transactions in the South has faster, stronger, more extroverted and open change level in organizational culture and leadership style than the North's units. The initiatives, innovations and applications of new technologies in Southern banking services are easy to implement and change than the North.

This result also gives some research implications for leaders and bank managers. The research shows that banks with more open and democratic and pursuing market-oriented signs tend to achieve better corporate performance. Therefore, to improve corporate performance, it is required for the banks to review the organizational culture administration, change the leadership style towards more openness and market orientation.

Fourth, although the state owned enterprise' human resource management often emphasizes the uniform in all-level managerial personnel's ideologies, morals, qualities and the work styles, in the commercial banks' corporate administration, the State of Vietnam does not plan to develop a model/ unique leadership style for different banks. All political and business leaders think that, as a developing country and with limited experience in market economy, it is essential for Vietnam to improve to learn more about the advanced countries' science, technology and skills in order to improve its business performance and sustainable development. Therefore, the theories and models of leadership style and organizational culture administration of H. Edgar Shein, Quinn, Cameron, Kennedy ... are being encouraged to study and apply for training and development of human resource as well as put into practice in Vietnamese organizational administration.

This study has achieved its original purpose as to consider a change of the leadership style between the two periods and differences in the change level among the bank groups and the business sectors. However, there remain certain limitations. The study failed to survey all existing state commercial banks, the results may be limited in its generalizability. The study also did not compare the state commercial bank groups to the private bank groups and the foreign bank groups, which resulted in an absence of comparative basis with these banks when considering their difference levels. These restrictions open opportunity for further research in the future.

\section{References}

Avolio, B. J., Bass, B. M., \& Jung, D. I. (1999). Re-examining the components of transformational and transactional leadership using the Multifactor Leadership. Journal of occupational and organizational psychology, 72(4), 441-462. https://doi.org/10.1348/096317999166789

Bass, B. M., \& Avolio, B. J. (1993). Transformational Leadership and Organizational Culture. Public Administration Quarterly, 12, 113-121.

Burns, J. M. (1978). Leadership. New York: Harper \& Row.

Conger, J., \& Kanungo, R. (1988). Charismatic Leadership: The Elusive Factor in Organizational Effectiveness. San Francisco, CA: Jossey Bass.

Deal, T., \& Kennedy, A. (1982). A Corporate Culture. Addison-Wesley, Reading, MA.

Demirtas, O., \& Akdogan, A. (2015). The effect of ethical leadership behavior on ethical climate, turnover intention, and affective commitment. Journal of Business Ethics, 130(1), 59-67. https://doi.org/10.1007/s10551-014-2196-6 
Dung, T. K., \& Trang, N. T. M. (2007). The influences of organizational culture and leadership style to employees' work results of and their loyalty to organizations. Ministerial Scientific Research, Ho Chi Minh City University of Economics, Ho Chi Minh City.

Harris, L. C., \& Ogbonna, E. (1999). Developing a market oriented culture: a critical evaluation. Journal of Management Studies, 36(2), 177-196. https://doi.org/10.1111/1467-6486.00132

Mahoney, T. A., Jardee, T. H., \& Allan, N. N. (1960). Predicting Managerial Effectiveness. Personnel Psychology, Summer, 147-163. https://doi.org/10.1111/j.1744-6570.1960.tb02462.x

Martin, J. (1992). Cultures in Organizations. New York: Oxford University Press.

Mullins, L. J. (1999). Management and Organizational Behavior. London: Financial Times.

Nguyen, H. M., \& Dao, T. K. (2015). Changes in Adaption to Organizational Culture Levels in Vietnamese Commercial Banks Before and After WTO Participation. Asian Social Science, 11, 104-111. https://doi.org/10.5539/ass.v11n26p104

Ogbonna, E., \& Harris, L. C. (2000). Leadership style, organizational culture and performance: empirical evidence from UK companies. International Journal of Human Resource Management, 11(4), 766-788. https://doi.org/10.1080/09585190050075114

Quinn, K. S. C., \& Robert, E. (2011). Diagnosing and Changing Organizational Culture: Based on The Competing Values Framework (3rd ed.). San Francisco: Jossey-Bass

Schein, E. H. (1992). Organizational Culture and Leadership (2th ed.). San Francisco: Jossey Bass.

Trice, H., \& Beyer, J. (1993). The Cultures of Work Organizations. Upper Saddle River, N.J.: Prentice Hall.

Yukl, G. (2010). Leadership in Organizations (7th ed.). New Jersey: Prentice Hall.

\section{Copyrights}

Copyright for this article is retained by the author(s), with first publication rights granted to the journal.

This is an open-access article distributed under the terms and conditions of the Creative Commons Attribution license (http://creativecommons.org/licenses/by/4.0/). 